\title{
Toxic Effect of African Black Soap (Sabulun salo) on the Histology of Albino Rat Stomach
}

\author{
O. M. Mohammed ${ }^{1 *}$, A. Umar ${ }^{1}$, A. S. Ajayi ${ }^{2}$, I. Mohammed ${ }^{1}$ \\ and A. O. Muhammed ${ }^{1}$ \\ ${ }^{1}$ Department of Histopathology, Faculty of Medical Laboratory Science, Usmanu Danfodiyo University, \\ Sokoto, Nigeria. \\ ${ }^{2}$ Department of Morbid Anatomy and Forensic Medicine, Usmanu Danfodiyo University Teaching \\ Hospital (UDUTH), Sokoto, Nigeria.
}

Authors' contributions

This work was carried out in collaboration between all authors. Author OMM designed the study, wrote the protocol and interpreted the data. Authors AU and ASA anchored the laboratory procedures,

the initial data and performed preliminary data analysis. While authors IM and AOM managed the literature searches and produced the initial draft. All authors read and approved the final manuscript.

Article Information

DOI: 10.9734/AJMAH/2016/28992 Editor(s):

(1) John K. Triantafillidis, Associate Professor, lasi University of Medicine and Pharmacy, Romania and IASO General Hospital, Holargos, Athens, Greece.

(2) Janvier Gasana, Department of Environmental \& Occupational Health, EO Epidemiology, and EO Medicine, Robert Stempel College of Public Health \& Social Work, Florida International University, USA.

Reviewers:

(1) Aliyu Ahmad Warra, Kebbi State University of Science \& Technology, Aliero, Kebbi State, Nigeria.

(2) Sahdeo Prasad, University of Texas MD Anderson Cancer Center, USA. (3) Nermeen Mohamed Shaffie, National Research Center, Cairo, Egypt. (4) Maria de Lourdes Pereira, University of Aveiro, Portugal. Complete Peer review History: http://www.sciencedomain.org/review-history/16671

Original Research Article

Received $16^{\text {th }}$ August 2016 Accepted $20^{\text {th }}$ October 2016 Published $26^{\text {th }}$ October 2016

\begin{abstract}
Background: Sabulun salo (African traditional black soap) is widely used among various local communities in the northern Nigeria as medicinal herb. This experimental research was carried out to study the effect of oral administration of the soap on the stomach of Albino Rats. The administration lasted for the period of two weeks.

Objectives: The objectives are to determine the effect of African black soap (Sabulun salo) on the histology of stomach, hematological parameters and food and water consumption.

Methodology: 20 Albino rats used for this study were randomly divided into four groups. The first, second and third group (AC, BC, and FC) were orally administered with $2000 \mathrm{mg} / \mathrm{kg}, 3000 \mathrm{mg} / \mathrm{kg}$ and $4000 \mathrm{mg} / \mathrm{kg}$ doses of Sabulun salo respectively. The control group received normal saline, the
\end{abstract}


animals were sacrificed under chloroform anaesthesia. The stomach was excised and processed for paraffin embedding. Blood samples were collected for haematological analyses.

Results: Incomplete metaplasia of the stomach epithelia were seen in the albino rats fed with $2000 \mathrm{mg} / \mathrm{kg}$ and $3000 \mathrm{mg} / \mathrm{kg}$ of the extract while complete metaplasia were observed among those on $4000 \mathrm{mg} / \mathrm{kg}$. There were significant increase in white blood cell, hemoglobin and packed cell volume in the entire groups except the FC group when compared to control. There was decrease in food and water consumption across the groups

Conclusion: The results of this research have shown that the Sabulun salo (African traditional black soap) is toxic to the albino rats exposed.

Keywords: Sabulun salo; histological; albino rat; toxic effect; stomach.

\section{INTRODUCTION}

African traditional black soap is the type of soap that is widely used among various communities within and outside the African continents [1]. The name varies among various communities in Africa. It is widely refered to as Sabulun salo, ose dudu among the Yoruba and in Igbo as Nchankota [2]. This legend black soap was introduced in Ghana from Nigeria many years ago by Yoruba traders doing business in Ghana [2]. Traditionally, African black soap which has in combination of water, roasted plaintain skin or cocoa pad, palm oil, palm kerned oil or Shea butter when put together, is collectively referred to as black soap [1]. Traditional medicine as described as the combination of knowledge, practice and belief incorporating plant, animal and mineral based medicine whether explicate or not, used in diagnosis, preventing or eliminating a physical, mental or social diseases and which may rely exclusively on past experience from generation to generation either verbally or in writing [3,4]. African Black Soap has numerous benefit and importance [1]. The African Black Soap has the ability of improving or eliminating uneven skin tone, razor bumps caused by ingrown hairs and skin rashes. It is an excellent for cleaning up oily skin, acne due to its antiseptic properties. It is also used to prevent skin from the rashes, ring worm measles, eczema and body odor. It is used in the treatment of many infectious diseases caused by micro-organism. Black soap is highly used for African spiritual purification [5]. However, Sabulun salo is special form of African Black Soap mainly used in the northern part of Nigeria. This type is devoid of artificial caustic soda, perfume, color and any other additives used in other types of African Black Soaps [6]. It is produced from the ash of straw of millet and oil. The oil could be any of palm oil, groundnut oil, palm kernel oil, Shea butter. These types of African Black Soap are highly medicinal as it is used orally for the treatment of various forms of gastrointestinal tract infection. It is generally used in the northern part of Nigeria for, cleaning and washing of stomach of toxic substances. The chemical constituents of Sabulun salo are potassium hydroxide, sodium hydroxide, fatty acid, glycerol and other trace elements which includes selenium, copper, lead and cadmium [7].

The aim of this study is to determine the effect of oral administration of Sabulun salo on the stomach organ, biochemical and hematological parameters of the albino rats.

\section{MATERIALS AND METHODS}

\subsection{Test Substance}

The Sabulun salo used in this study was bought from the Shehu Shagari central market in Sokoto, Nigeria.

\subsection{Animal Husbandry}

Albino rats (About 3 weeks old) of either sex, bred in the animal house of Faculty of Pharmaceutical Sciences of Ahmadu Bello University Zaria, Nigeria, were used for the research. The animal were transferred into the animal house of the Faculty of Pharmaceutical Sciences of Usmanu Danfodiyo University Sokoto, Nigeria. They were housed in a meshed bottom cage and left for about 6 weeks for maturity and acclimatization under continuous $12 \mathrm{~h}$ light/darkness and fed with pelletized feed from FA feeds, Sokoto. The ethical standard of handling the laboratory animals was completely adhered to during the study.

\subsection{Experimentation}

The total number of twenty albino rats was used for the study. The concentrations (2000, 3000 
and 4000$) \mathrm{mg} / \mathrm{kg}$ of weight of the sabulun salo solution were prepared. And the dose is based on the LD50 which greater than $5000 \mathrm{mg} / \mathrm{kg}$.

The experiment commenced on $4^{\text {th }}$ June, 2015, six weeks after the purchase of the albino rats and was allowed to stay for about 14 days. At the end of the $14^{\text {th }}$ day, the rats were sacrificed and the blood and the stomach organ were removed. Stomach was processed for histology.

\subsection{Hematological Examination}

The albino rats sedated with chloroform in the laboratory. Total death was prevented to allow for continuous flow of blood for proper blood collection. The blood was then collected from the cardiac puncture using syringe and needle. And it was discarded into plane and EDTA bottle. The blood parameters (PCV, Hbg, WBC, Platelets and Differential Leucocytes) were determined using sysmex auto-analyzer.

\subsection{Statistical Analysis}

The multiple comparison of the weights, haematological and biochemical scores were analyzed by ANOVA followed by Tukey's test. The difference between groups was considered significant when $P<0.05$.

\section{RESULTS AND DISCUSSION}

The albino rats were divided into experimental group of fifteen animals and the control group of five animals. The experimental group was divided group $A C, A B$ and $F C$. And the groups were administered 2000, 3000 and $4000 \mathrm{mg} / \mathrm{kg}$ of Sabulun salo respectively. From Fig. 1, there are decreases in both food and water consumptions as the concentrations of the Sabulun salo increase along the groups when compared to control. The haematological values obtained for animals fed with different doses of Sabulun salo are presented in Table 1. The results indicated that WBC, HBG and PCV increase significantly $(p<0.05)$ in the entire groups except those animals in group FC (on the highest dose) when compared with control. The platelets increase significantly $(p<0.05)$ in the entire groups when compared with control. The lymphocytes increase significantly $(p<0.05)$ in the group $B C$, decrease significantly $(p<0.05)$ in the group FC and the results also indicated that there are no significant differences in the group AC when compared to control.
The Monocytes decrease significantly $(p<0.05)$ in the group BC and FC when compared to control and the group AC showed no significant difference when compared to control.

The granulocytes showed no significant difference in the entire groups except those in group FC (on the highest dose) which increase significantly $(p<0.05)$ when compared to control.

The reduction of the water and food consumption of the exposed albino rats may be due to the irritation of the gastrointestinal tract of the albino rats caused by the Sabulun salo solution ingestion. The reduction of water and food consumption in the exposed group also support the reported findings [8] that sub lethal concentration of soap reduced the food consumption and the weight of catfish. It was observed that chronic exposure of soap also reduced food consumption and retard the growth of the sea bass larvae exposed significantly [9]. However, the result did not observe any significant reduction in the growth, food and water consumption in albino rats exposed to the soap and detergents [10]. Poor physiological conditions of the exposed rats can lead to the loss of appetite [11]. The fact that stomach organ of the exposed rats showed a marked histopathological changes confirm that the soap has an adverse effect on the albino rats. The histopathological changes were as a result of cytotoxic agents [11] in the soap solution which caused multi organs injuries. Intestinal metaplasia is associated with the transformation of the stomach lining and in the earlier stages, the replaced epithelium resembles the small intestine [12]. There is no precise information on the causes of the intestinal metaplastic disorder has been obtained so far [12]. However, medical expert believe that gastroesophageal reflux disease, a condition in which the acid content of stomach could lead to metaplasia of the stomach [12].

This result supports research findings that ingestion of soap solution can cause multi organ damage leading to nervous system disorders, respiratory illness, cancer and even death $[13,14]$. Furthermore, the result is in line with reported pathological changes in animal and plant exposed to soap [15,16]. However, this study did not find cancer changes which has been suspected by some researchers [17], probably due to the short duration of the study.

Sodium silicate and potassium hydroxide, a major components of soap has been fingered in 
gastrointestinal irritation leading to nausea, severe digestive tract burns and weight loss in an exposed animal $[18,19]$. Reduction in the blood parameters (WBC, Platelets, PCV, HBG and Differential) of the exposed albino rats compared to the control rat confirm the earlier report of blood parameters reduction in rabbit exposed to the soap [19]. The reduction in the blood parameters was as a result of destruction of the cells of the albino rat by the traces of amounts of heavy metals found in the soap [20]. It was reported that blood of an animal may be adversely affected by soap used as anti bacteria because they do so by killing cells. The increase in the WBC of the exposed albino rats was as a result of immune response of the albino rat to the toxic components of the soap solution [21]. The reason for the non dose and non significant dependency data may be due the short duration of the research.

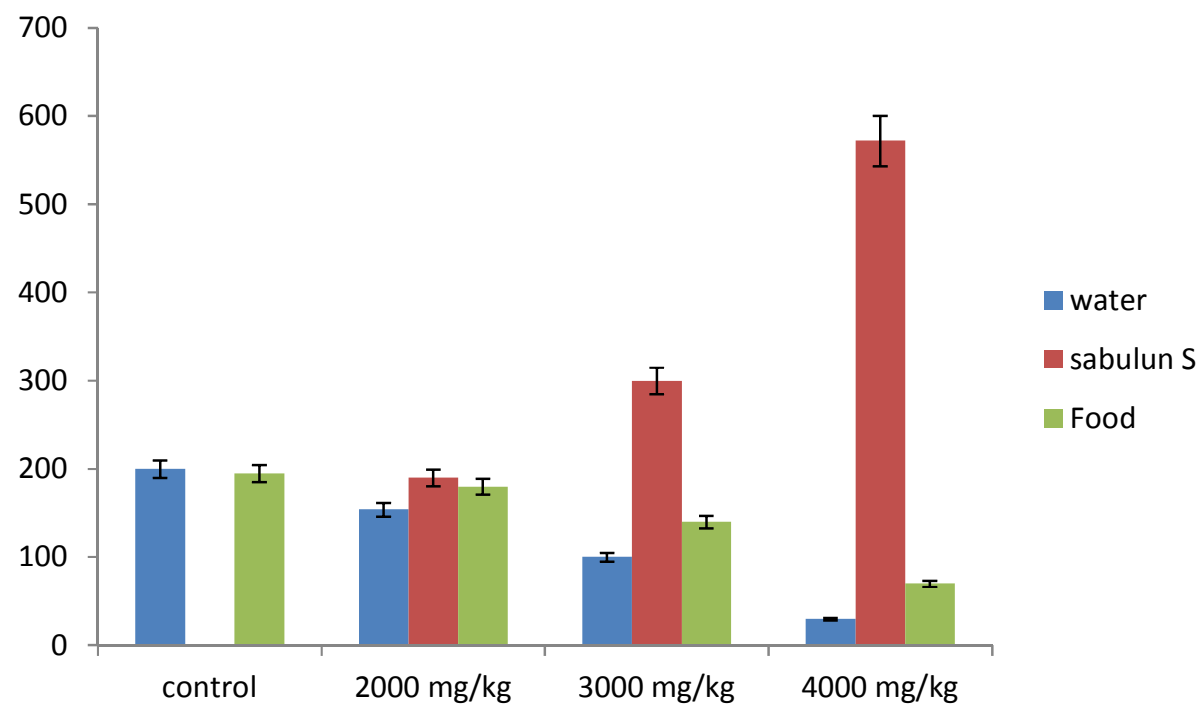

Fig. 1. Effect of Sabulun salo on food and water consumption

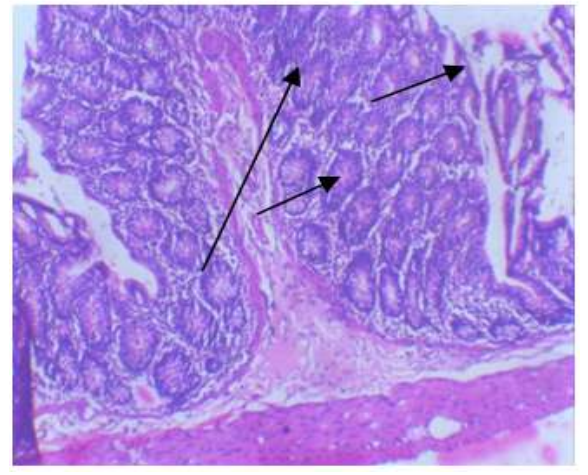

Fig. 2. Control group of stomach histology showing the short foveolae (long arrow) and the tightly packed glands. Purplish zymogenic cells predominate at the base, and pinkish parietal cells predominate in the upper part of the glands (short arrow)

$H \& E X 100$

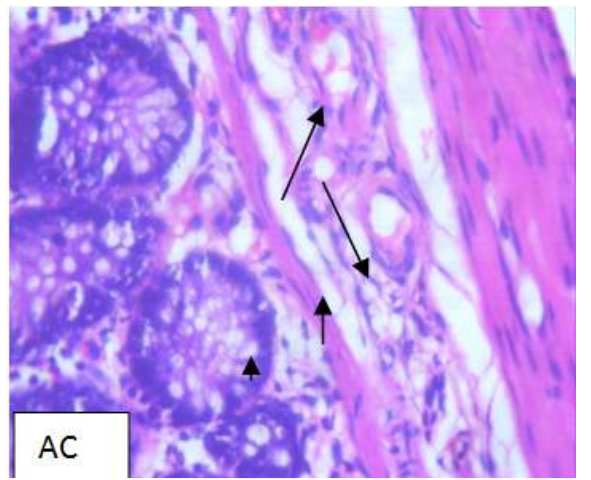

Fig. 3. AC group stomach histology showing an incomplete intestinal metaplasia. The epithelium consists of a mixture of intestinal-type goblet cells (long arrow) and columnar mucus-secreting cells, morphologically resembling those of the normal gastric epithelium (short arrow). H\& E X 400 


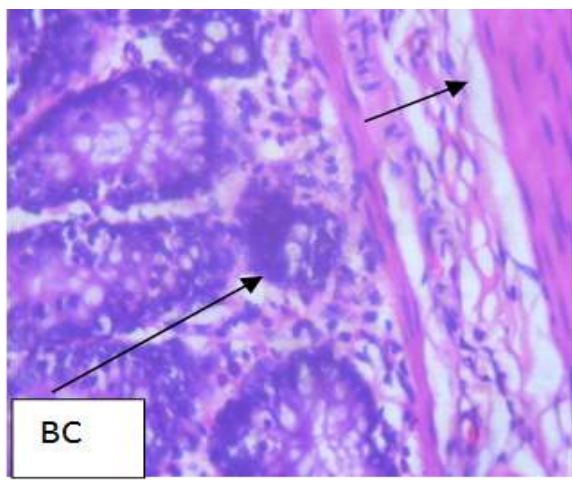

Fig. 4. BC group stomach histology showing the epithelium consists of a mixture of intestinal-type goblet cells (short arrow) and columnar mucus-secreting cells, morphologically resembling those of the normal gastric epithelium (long arrow). H\&E $\times 400$

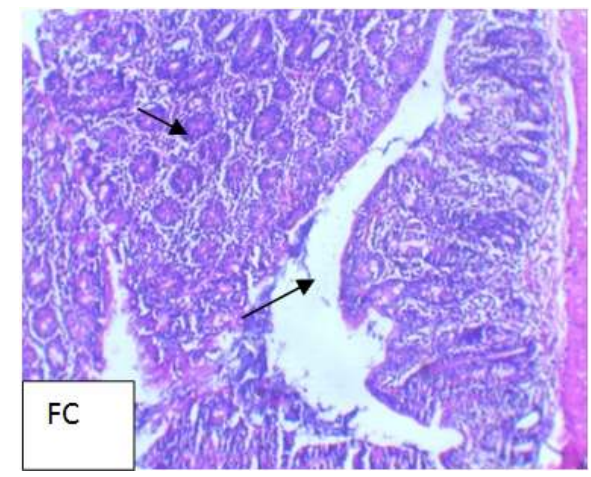

Fig. 5. FC group stomach histology Showing a complete intestinal metaplasia with fully developed goblet cells (short arrow) and the contour of the mucosa changes with the development of villi (long arrow). H\&E X100

Table 1. Hematological parameters of the experimental groups

\begin{tabular}{lllll}
\hline Parameters & \multicolumn{4}{c}{ Groups } \\
\cline { 2 - 5 } & Control & Group AC & Group BC & Group FC \\
\hline WBC $\left(\times 10^{-3} \mu \mathrm{l}\right)$ & $4.10 \pm 0.00^{\mathrm{a}}$ & $4.80 \pm .10^{\mathrm{b}}$ & $4.74 \pm .11^{\mathrm{bc}}$ & $2.78 \pm .24^{\mathrm{d}}$ \\
HBG $(\mathrm{g} / \mathrm{dl})$ & $11.30 \pm 0.00^{\mathrm{b}}$ & $11.82 \pm 0.26^{\mathrm{c}}$ & $11.42 \pm 0.34^{\mathrm{ab}}$ & $11.24 \pm 0.09^{\mathrm{bd}}$ \\
PCV $(\%)$ & $45.00 \pm 0.00^{\mathrm{c}}$ & $49.60 \pm 1.82^{\mathrm{b}}$ & $45.40 \pm 0.55^{\mathrm{ac}}$ & $44.82 \pm 0.61^{\mathrm{cd}}$ \\
Platelets $\left(10^{3} / \mu \mathrm{l}\right)$ & $545 \pm 0.00^{\mathrm{a}}$ & $693.2 \pm 28.86^{\mathrm{b}}$ & $798.6 \pm 116.95^{\mathrm{c}}$ & $611.80 \pm 47.97^{\mathrm{ab}}$ \\
Lymphocyte $(\%)_{\text {Monocytes }(\%)}^{88.10 \pm 0.00^{\mathrm{d}}}$ & $87.48 \pm 1.21^{\mathrm{d}}$ & $89.12 \pm 0.91^{\mathrm{dd}}$ & $45.76 \pm 1.84^{\mathrm{b}}$ \\
Granulocytes $(\%)$ & $4.60 \pm 0.00^{\mathrm{e}}$ & $4.86 \pm 0.37^{\mathrm{e}}$ & $4.04 \pm 0.21^{\mathrm{b}}$ & $3.00 \pm 0.40^{\mathrm{c}}$ \\
\hline & $7.30 \pm 0.00^{\mathrm{a}}$ & $7.46 \pm 1.15^{\mathrm{a}}$ & $6.80 \pm 0.78^{\mathrm{a}}$ & $51.24 \pm 2.01^{\mathrm{b}}$ \\
\hline
\end{tabular}

Values are presented as mean $\pm S D$. Values with different superscripts per row are significantly different $(p<0.05)$. $W B C=$ white blood cell, $H B G=$ haemoglobin level, $P C V=$ packed cell volume

\section{CONCLUSION}

The results of this research have shown that the Sabulun salo (African traditional black soap) is toxic to the albino rats exposed. Finally, it is hoped that the result from this investigation will enlighten people on the health risk posed by Sabulun salo consumption.

\section{CONSENT}

It is not applicable.

\section{COMPETING INTERESTS}

Authors have declared that no competing interests exist.

\section{REFERENCES}

1. Aliyu GM, Malik Al, Kashari O. Analysis of the antibacterial activity of African Black soapon some selected pathogens. ARPN Journal of Science and Technology. 2012; 2:2225-7217.

2. Beauty out of African; 2011. (Accessed on $7^{\text {th }}$ march, 2015) Available:atshearadiance.typepad.com/she a-radiance/

3. Sofowora A. Medical Plants and Traditional Medicine in Africa, $1^{\text {st }}$ Edtion. John Wiley Andsons Limited. 1982;68-69.

4. David O. Brief history of black soap and ingredients (Plantain skin). 2005;19:3. (Accessed on $27^{\text {th }}$ August, 2015) Available:htt//www.oakfordavid.com

5. Karen A. Black Sppoopftyoap Story: Traditional Soap Making in Ghana; 2001. (Accessed on $7^{\text {th }}$ march, 2015) Available:http//www.yendordrums.com.14t h August 2014

6. Taiwo OE, Osinowo FA. Evaluation of various agro waste for traditional black 
soap production. Science Direct Journal. 2001;79:95-97.

7. Simmon WH, Appleton HA. The Handbook of Soap Manufacture. The Oil and Colour Trades Journal. London Scott, Greenwood and Son office 8 Broadway, Ludgate Hill, E.C; 2007.

(Accessed on $3^{\text {rd }}$ Febuary, 2015)

Available:http://www.gutenberg.org

8. Esenowo IK, Ugwumba OA. Growth response of cat fish (Clarias gariepinus) exposedto water soluble fraction of detergent and diseal oil. Environmental Research Journal. 2010;4:298-301.

9. Rejeki S, Desrina D, Mulgana RA. Chronic effect of detergent surfactant linear alkylbenzene sulfonate on the growth and survival rate of sea bass (Lates Calcalifer Block) larvae. Agriculture Study Program Fisheries Department, Faculty of Fisheries and Marine Science, Diponegaro University, Semarang, Indonesia. 2006;118.

10. Faremi AY, Oloyede OB. Biochemical assessment of the effect of soap and industrial effluent on some enzymes in the stomach of albino rats. Research Journal of Environmental Toxicology. 2010;4:127133.

11. Ogunbileje JO, Akinosun MO. Biochemical and hematological profile in Nigeria cement factoring workers. Research Journal of Environmental Toxicology. 2011;4:123-157.

12. Madhulima A, Intestinal Metaplasia; 2016.

(Accessed on $12^{\text {th }}$ October, 2016)

Available:www.hxbenefit.com/inestinalmetaplasia.html

13. Ayandiran TA, Fawole OO, Adewoye SO, Ogundiran MA. Bio-concentration of metal in the body muscle and gut of Claris gariepinus exposed to sub lethal concentration of soap and detergent effluent. Journal of Cell and Animal Biology. 2009;3:113-118.
14. Gholami M, Fatemi SMR, Falahi M, Esmaili A, Mashinchiyan A. Effect of heavy metal (copper and cadmium) and detergent on white fish fry Rutilus frisii kutum. Research Journal of Environmental Toxicology. 2010;4:231-236.

15. Akanji MA, Olagoke OA, Olayode OB. Effect of chronic consumption of metal bisulphateon the integrity of rat liver cellular system. Toxicity. 1993;81:173-179.

16. Uaboi-Egbenni PO, Okolie PN, Adejuyitan OE, Sobande AO, Akinyemi O. Effect of industrial effluents on the growth and anatomical structures of Abelmoschus esculeutus. African Journal of Biotechnology. 2009;8:3251-3260.

17. Kassem N. Allergens and toxin in laundry detergent: Synthetic Ingredient that are Harmfulto People and the Environment; 2010.

(Accessed on $3^{\text {rd }}$ Febuary, 2015)

Available:http://organizedwisdom.com/aller gens-and-toxins-in-laundry-detergentssynthetic-ingredient-that-are-harmful-topeople

18. Warne MJ, Schifko AD. Toxicity of loundary detergent components to a fresh water cladoceran and their contribution to detergent toxicity. Ecotoxicology and Safety. 1999;44:196-206.

19. Wadaan MA, Mubarak M. Blood chemistry changes as an evidence of the toxic effect of anionic surfactant dodecyl sulphate. Asian Journal of Scientific Research. 2009; 2:113-118.

20. Abulude FO, Ogunkoya MO, Ogunleye RF, Emidun O, Abulude Al. Assessment of thecontent of $\mathrm{Pb}, \mathrm{Cd}, \mathrm{Ni}$ and $\mathrm{Cr}$ in soap and detergents from Akure, Nigeria. Research Journal of Environmental Toxicology. 2007;1:102-104.

21. Riaz SA, Ahmed S, Hasnain DS. Antibacterial activities of soap against daily encountered bacteria. African Journal of Biotechnology. 2009;8:1431-1436.

(c) 2016 Mohammed et al.; This is an Open Access article distributed under the terms of the Creative Commons Attribution License (http://creativecommons.org/licenses/by/4.0), which permits unrestricted use, distribution, and reproduction in any medium, provided the original work is properly cited. http://sciencedomain.org/review-history/16671 